\title{
Preparation of MnCo/MCM-41 catalysts with high performance for chlorobenzene combustion
}

\author{
Zhen Cheng, Jingrong Li, Peng Yang, Shufeng Zuo * \\ Zhejiang Key Laboratory of Alternative Technologies for Fine Chemicals Process, Shaoxing University, Shaoxing 312000, Zhejiang, China
}

\section{A R T I C L E I N F O}

\section{Article history:}

Received 18 Novermber 2017

Accepted 25 December 2017

Published 5 April 2018

\section{Keywords:}

MCM-41

$\mathrm{Mn} / \mathrm{Co}$

Catalytic combustion

Chlorobenzene

Characterization

\begin{abstract}
A B S T R A C T
MCM-41 was synthesized by a soft template technique. The specific surface area and pore volume of the MCM-41 were $805.9 \mathrm{~m}^{2} / \mathrm{g}$ and $0.795 \mathrm{~cm}^{3} / \mathrm{g}$, respectively. MCM-41-supported manganese and cobalt oxide catalysts were prepared by an impregnation method. The energy dispersive X-ray spectroscopy clearly confirmed the existence of $\mathrm{Mn}$, Co, and $\mathrm{O}$, which indicated the successful loading of the active components on the surface of MCM-41. The structure and function of the catalysts were changed by modulating the molar ratio of manganese to cobalt. The $10 \% \mathrm{MnCo}(6: 1) / \mathrm{MCM}-41$ (Mn/Co molar ratio is 6:1) catalyst displayed the best catalytic activity according to the activity evaluation experiments, and chlorobenzene $(1000 \mathrm{ppm})$ was totally decomposed at $270{ }^{\circ} \mathrm{C}$. The high activity correlated with a high dispersion of the oxides and was attributed to the exposure of more active sites, which was demonstrated by $\mathrm{X}$-ray diffraction and high-resolution transmission electron microscopy. The strong interactions between $\mathrm{MnO}_{2}, \mathrm{Co}_{3} \mathrm{O}_{4}, \mathrm{MnCoO}_{\mathrm{x}}$, and MCM-41 indicated that cobalt promoted the redox cycles of the manganese system. The bimetal-oxide-based catalyst showed better catalytic activity than that of the single metal oxide catalysts, which was further confirmed by $\mathrm{H}_{2}$ temperature-programmed reduction. Chlorobenzene temperature-programmed desorption results showed that 10\%MnCo(6:1)/MCM-41 had higher adsorption strength for chlorobenzene than that of single metal catalysts. And stronger adsorption was beneficial for combustion of chlorobenzene. Furthermore, $10 \% \mathrm{MnCo}(6: 1) / \mathrm{MCM}-41$ was not deactivated during a continuous reaction for $1000 \mathrm{~h}$ at $260^{\circ} \mathrm{C}$ and displayed good resistance to water and benzene, which indicated that the catalyst could be used in a wide range of applications.
\end{abstract}

(C) 2018, Dalian Institute of Chemical Physics, Chinese Academy of Sciences. Published by Elsevier B.V. All rights reserved.

\section{Introduction}

Volatile organic compounds (VOCs) are chemicals that are defined by a saturated vapor pressure that exceeds $70 \mathrm{~Pa}$ at room temperature or a boiling point that is lower than $260{ }^{\circ} \mathrm{C}$ at standard pressure. They are present in haze, photochemical smog, and contribute to the greenhouse effect. They are also involved in the depletion of atmospheric ozone and the production of ground-level ozone [1,2]. In particular, chlorinated volatile organic compounds (CVOCs), which are highly toxic, are difficult to decompose in air because of the occurrence of polychlorinated byproducts, being increasingly one of the VOCs which handle hardly [3]. The CVOCs, as semi-finished chemical products, are widely used as solvents for dry cleaning and degreasing processes in industrial manufacturing $[4,5]$.

Generally, the techniques for the destructive removal of CVOCs include high-temperature direct combustion, catalytic hydrodechlorination, catalytic steam reforming, photocatalytic oxidation, and catalytic combustion. Compared with other techniques, catalytic combustion is applied in a wide range of applications because of its lower energy consumption, lower handling temperature, and higher purification efficiency.

\footnotetext{
* Corresponding author. Tel: +86-575-88345681; Fax: +86-575-88345682; E-mail: sfzuo@usx.edu.cn

This work was supported by the National Natural Science Foundation of China (21577094).

DOI: 10.1016/S1872-2067(17)62950-4 | http://www.sciencedirect.com/science/journal/18722067 | Chin. J. Catal., Vol. 39, No. 4, April 2018
} 
For the catalytic combustion of CVOCs, catalyst support materials with a large specific surface area and pore volume, which are beneficial for the dispersion of the active substances, are always prevalent. They usually consist of molecular sieves (such as $\gamma-\mathrm{Al}_{2} \mathrm{O}_{3}$, HFAU, HZSM-5, MCM-41), metal oxides, and honeycomb ceramics [3]. Compared with other two supports, molecular sieves not only have better thermal stability, but also possess higher specific surface areas and more acidic sites [6]. However, the problem of carbon deposition is yet to be solved. As a nanostructured material, MCM- 41 with a hexagonal ordered pore arrangement and large adsorption quantity was first discovered in 1992 [7]. It has been widely applied in resid catalytic cracking, heavy oil catalytic hydrogenation, alkyl isomerization, and macromolecular fine chemicals. Furthermore, it is completely composed of silica and has no acidity, effectively avoiding the issue of carbon deposition.

Currently, the catalysts used for the destruction of CVOCs can be classified into two types according to their active components, including noble metals catalysts [8-10] and non-noble metal catalysts. In practice, noble-metal-based catalysts show higher activity. However, they are more expensive and undergo deactivation because of chlorine poisoning and the formation of polychlorinated compounds. Therefore, many efforts have been devoted to the synthesis of transition-metal oxide catalysts [11-16] because they resist deactivation to a larger extent and are cheaper. Usually, metal oxides (such as $\mathrm{V}_{2} \mathrm{O}_{5}, \mathrm{Cr}_{2} \mathrm{O}_{3}, \mathrm{MnO}_{2}$, $\mathrm{Co}_{3} \mathrm{O}_{4}$ and $\mathrm{NiO}$ ) or composite metal oxides are used as active components of transition metal oxide catalysts. In particular, manganese and cobalt oxides possess better activity, lower cost, and create little or no environmental pollution. Therefore, they have been widely used both domestically and internationally $[17,18]$. However, when use only one component, the loss of active sites (which could adsorb $\mathrm{HCl}$ and/or $\mathrm{Cl}_{2}$ ) or the formation of volatile species (metal chloride or metal chloride oxide) at lower temperature may cause partial deactivation of these transition metal oxides catalysts, which may restrict the applications of transition metal oxides catalysts [19]. Thus, composite metal oxides catalysts have been reported, which improve the mobility of the surface-active oxygen and increase the surface acidic sites through the synergistic effect of the metal-metal and metal-support interactions.

There have been numerous reports of molecular-sieves-supported transition-metal oxides as catalysts that have been used to eliminate CVOCs [20-27]; for example, $\mathrm{Cu}-\mathrm{ZSM}-5$ [26] and $\mathrm{Cr}_{2} \mathrm{O}_{3}-\mathrm{CuO} / \mathrm{HZSM}-5$ [27]. Furthermore, the MCM-41 as a catalyst support, its applications for the destruction of CVOCs have also been reported, including Pt/P-MCM-41, La/MCM-41, Ce/MCM-41, and Pt/MCM-41, which showed a high catalytic performance [28-30]. In the catalytic combustion field of CVOCs, there are rarely reports about MCM-41 supported MnCo catalysts for destruction of chlorobenzene (CB). Therefore, we synthesized MCM-41-supported MnCo catalysts for CB combustion.

In this paper, we prepared MCM-41-supported MnCo catalysts, and explored their catalytic performance for combustion of CB in air. Furthermore, the synergistic effect between Mn (the main active phase), Co (the second active phase) and
MCM-41 was studied. The catalysts were analyzed by X-ray diffraction (XRD), high-resolution transmission electron microscopy (HRTEM), and energy dispersive X-ray spectroscopy (EDS), nitrogen $\left(\mathrm{N}_{2}\right)$ adsorption-desorption, temperature-programmed reduction of hydrogen $\left(\mathrm{H}_{2}\right.$-TPR), and temperature-programmed desorption of CB (CB-TPD). Furthermore, the activity and durability of the materials was evaluated to further investigate the performance of the catalysts.

\section{Experimental}

\subsection{Synthesis}

The MCM-41 was prepared according to the following procedure. Tetrabutylammonium silicate (TBAS) was obtained from tetrabutylammonium hydroxide (TEAOH, $40 \mathrm{wt} \%$, Aldrich) and fumed silica (Sigma) in a 10:1 ratio. Then, $12.21 \mathrm{~g}$ of TBAS was combined with $20.3 \mathrm{~g}$ of cetyltrimethylammonium chloride (CTAC, $25 \mathrm{wt} \%$, Aldrich) and $5.94 \mathrm{~g}$ of $\mathrm{H}_{2} \mathrm{O}$ under stirring, followed by the addition of $5.91 \mathrm{~g}$ of fumed silica. The resulting gel was placed in a Teflon bottle and heated for $120 \mathrm{~h}$ at $100{ }^{\circ} \mathrm{C}$ to perform the crystallization. After cooling to room temperature, the solid product was recovered by filtration, washed thoroughly with deionized water, and dried in an oven at $80^{\circ} \mathrm{C}$ overnight. Finally, the template CTAC was removed by calcination in a stream of air at $550{ }^{\circ} \mathrm{C}$ for $5 \mathrm{~h}$ [31]. A series of $\mathrm{MnCo} / \mathrm{MCM}-41$ catalysts with different molar ratios of $\mathrm{Mn} / \mathrm{Co}$ (3:1, 6:1, and 9:1) were prepared by co-impregnation of MCM-41 with an aqueous solution of $\mathrm{Mn}\left(\mathrm{NO}_{3}\right)_{2}(50 \%)$ and $\mathrm{Co}\left(\mathrm{NO}_{3}\right)_{3} \cdot 6 \mathrm{H}_{2} \mathrm{O}$ overnight. Then, the samples were stirred in the electrothermal setup until desiccation. Later, calcination was performed at $500{ }^{\circ} \mathrm{C}$ for $2 \mathrm{~h}$. The particles with a 40-60 mesh size were sieved to obtain the products. The total content of the single metal (Mn or Co) and mixed MnCo (the sum of both $\mathrm{Mn}$ and $\mathrm{Co}$ ) for all the catalysts was $10 \mathrm{wt} \%$.

\subsection{Catalytic activity test}

The activity evaluation of the catalysts $(350 \mathrm{mg}$ ) was performed in a WFS-3010 microreactor (Xianquan, Tianjin, China), in which the space velocity was $20000 \mathrm{~h}^{-1}$ and the concentration of $\mathrm{CB}$ was $1000 \mathrm{ppm}$. The concentration of $\mathrm{O}_{2}$ in the gas flow stream was $21 \%$. The on-line measurements were conducted using a Shimadzu GC-14 (Japan), which had a flame ionization detector (FID). The temperatures of the vaporizer and column were both $120{ }^{\circ} \mathrm{C}$. The data were obtained and analyzed using a N2000 chromatography data workstation. The degradation products were detected by mass spectrometry (MS, QGA, Hiden, UK). No byproducts other than $\mathrm{H}_{2} \mathrm{O}, \mathrm{CO}_{2}$, and $\mathrm{HCl}$ were detected. Thus, the conversion was calculated based on $\mathrm{CB}$ consumption. The durability of the catalysts for $\mathrm{CB}$ combustion was also investigated under the same conditions.

\subsection{Characterization}

The composition of the catalyst phase was determined by XRD, which was performed with a PANalytical EMPYREAN 
powder diffractometer operated with a $\mathrm{Cu} K_{\alpha}$ source $(\lambda=$ $0.15406 \mathrm{~nm}$ ). The experimental conditions were as follows: tube current of $40 \mathrm{~mA}$, tube voltage of $40 \mathrm{kV}$, scanning rate of $0.02^{\circ} \mathrm{s}$ and scanning limitation of $10^{\circ}-80^{\circ}$.

HRTEM was carried out using a JEOL-2010 to investigate the morphologies of MCM-41 and 10\% MnCo (6:1)/MCM-41. The working voltage was $200 \mathrm{kV}$. The elements present in the catalyst were determined by EDS using an OXFORD INCA instrument (Oxford Instruments, UK).

The specific surface area and pore volume of the catalysts were measured by a Tristar II 3020 apparatus (Micromeritics Company, USA), by using the $\mathrm{N}_{2}$ adsorption-desorption technique $\left(-195.8^{\circ} \mathrm{C}\right)$. The sample was pretreated at $200^{\circ} \mathrm{C}$ for $4 \mathrm{~h}$. The specific total surface area $\left(A_{\mathrm{BET}}\right)$ was calculated using the Brunauer-Emmett-Teller (BET) equation, whereas the total pore volume $\left(V_{\mathrm{p}}\right)$ was evaluated from the nitrogen uptake at a relative $\mathrm{N}_{2}$ pressure of $p / p_{0}=0.99$. The Barrett-Joyner-Halenda method was used to calculate the average pore size.

The oxidation properties of the catalysts were determined by $\mathrm{H}_{2}$-TPR experiments. $50 \mathrm{mg}$ of the catalyst was pretreated at $450{ }^{\circ} \mathrm{C}$ in argon for $1 \mathrm{~h}$, after which the temperature was decreased to $50{ }^{\circ} \mathrm{C}$. When the adsorption of the organic compounds was at a state of dynamic balance, in other words, the base line was stable, and then the temperature was programmed to rise at a constant rate of $7.5^{\circ} \mathrm{C} / \mathrm{min}$ up to 450 ${ }^{\circ} \mathrm{C}$. Hydrogen uptake was measured with a thermal conductivity detector, and the compounds were detected by gas chromatography-mass spectrometry (GC-MS) (QGA, HIDEN, UK) on-line.

The CB-TPD experiments were performed in a quartz tube. Before the adsorption of $\mathrm{CB}, 350 \mathrm{mg}$ of catalyst was pretreated in dry air at $300{ }^{\circ} \mathrm{C}$ for $0.5 \mathrm{~h}$. After it was cooled down to $50{ }^{\circ} \mathrm{C}$, the adsorption of $\mathrm{CB}$ was carried out under a flow of $\mathrm{CB} / \mathrm{N}_{2}$ until adsorption saturation, which was symbolized by a stable $\mathrm{CB}$ signal in the mass spectrometer. Then, pure $\mathrm{N}_{2}$ was blown for $1 \mathrm{~h}$ to clean the $\mathrm{CB}$ of the tubing in the system. Finally, desorption of $\mathrm{CB}$ was implemented by flowing pure $\mathrm{N}_{2}$ at a temperature step of $7.5{ }^{\circ} \mathrm{C} / \mathrm{min}$ from 50 to $500{ }^{\circ} \mathrm{C}$. The concentration of CB was detected on-line by GC-MS [32].

\section{Results and discussion}

\subsection{Catalytic activity evaluation}

Fig. 1 shows the catalytic oxidation activity of different catalysts. The activity of the catalysts for CB combustion with $1000 \mathrm{ppm}$ decreased in the order: MnCo (6:1)/MCM-41 > MnCo (9:1)/MCM-41 > MnCo (3:1)/MCM-41 > Mn/MCM-41 > Co/MCM-41. The 10\% MnCo (6:1)/MCM-41 catalyst exhibited the highest activity, and the temperature for complete CB degradation was $270{ }^{\circ} \mathrm{C}$. The $10 \%$ MnCo (9:1)/MCM-41 catalyst exhibited a relatively low activity; this was attributed to the higher amount of Co. Too much Co loading could override the $\mathrm{MnO}_{x}$ sites (main active sites). The catalyst activity was also lower when the Mn/Co molar ratio was 3, as a consequence of the lack of oxygen vacancies. Thus, the appropriate loading of $\mathrm{Mn}$ and Co played an important role in improving the

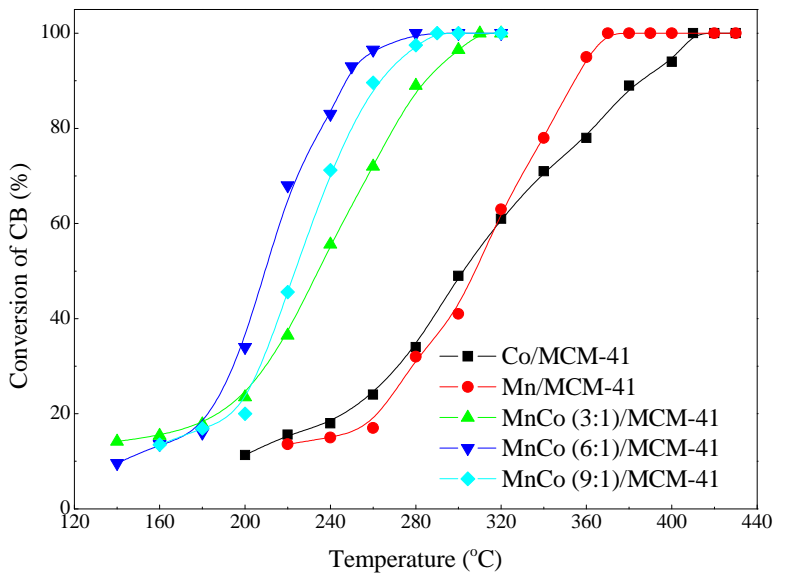

Fig. 1. The conversion curves of the catalytic combustion for $\mathrm{CB}$ over $\mathrm{MnCo} / \mathrm{MCM}-41$ catalysts with various Mn/Co molar ratios.

MnCo/MCM-41 activity. The catalytic activity of similar catalysts reported in the literature for the catalytic combustion of CB are listed in Table S1 [33-37], which shows that $10 \%$ MnCo (6:1)/MCM-41 had higher activity.

\subsection{Durability test}

Apart from catalytic activity, the durability of a catalyst is also very important in determining the performance of catalysts. The MnCo (6:1)/MCM-41 catalyst showed good durability in a continuous $1000 \mathrm{~h}$ reaction under dry air at 260 ${ }^{\circ} \mathrm{C}$ (Fig. 2). However, the conversion of $\mathrm{CB}$ dropped in the presence of benzene because of competitive adsorption. Notably, the conversion of CB decreased more when the water was also added, indicating that water also inhibited $\mathrm{CB}$ oxidation, because some active sites were overlapped. Nonetheless, the conversion of $\mathrm{CB}$ recovered without the presence of benzene and water.

\subsection{XRD analysis}

The XRD patterns are shown in Fig. 3. A big diffraction peak attributed to silica was observed at approximately $2 \theta=22.8^{\circ}$.

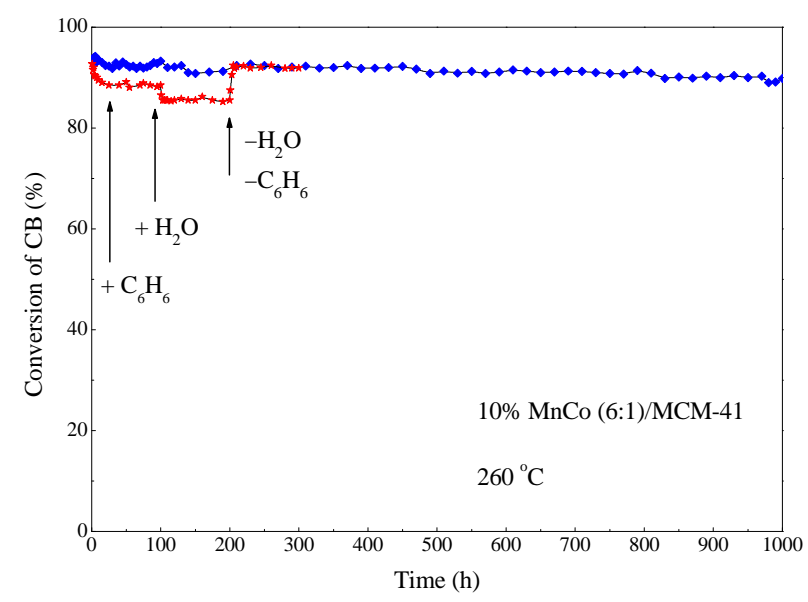

Fig. 2. Catalyst durability test profile for $10 \% \operatorname{MnCo}(6: 1) / M C M-41$. 


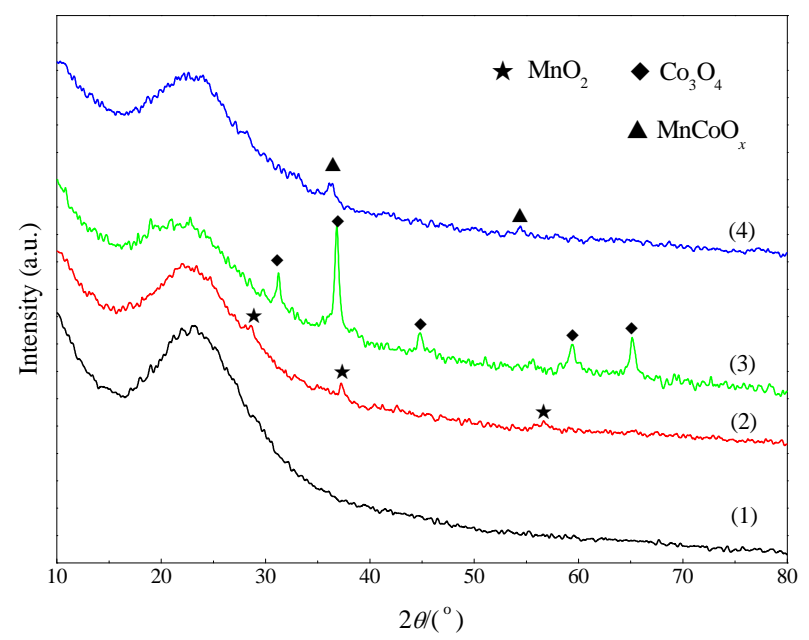

Fig. 3. XRD patterns of the samples. (1) MCM-41; (2) 10\% Mn/MCM-41; (3) 10\% Co/MCM-41; (4) 10\% MnCo (6:1)/MCM-41.

Meanwhile, the characteristic peaks of $\mathrm{MnO}_{2}$ and $\mathrm{Co}_{3} \mathrm{O}_{4}$ were detected in 10\% Mn/MCM-41 and 10\% Co/MCM-41. The peak of $\mathrm{MnCoO}_{x}$ was observed in 10\% MnCo (6:1)/MCM-41. In the $10 \%$ MnCo (6:1)/MCM-41 catalyst, two weakly intense peaks appeared at a diffraction angle $2 \theta$ of $36.0^{\circ}$ and $54.2^{\circ}$, which corresponded to the XRD patterns of $\mathrm{MnCo}_{2} \mathrm{O}_{4}$ and $\mathrm{CoMn}_{2} \mathrm{O}_{4}$, respectively [38]. Accordingly, we deduced the presence of
$\mathrm{MnCo}_{2} \mathrm{O}_{4}$ and $\mathrm{CoMn}_{2} \mathrm{O}_{4}$. The presence of $\mathrm{Co}_{3} \mathrm{O}_{4}, \mathrm{CoO}, \mathrm{MnO}$, $\mathrm{Mn}_{3} \mathrm{O}_{4}, \mathrm{Mn}_{2} \mathrm{O}_{3}$, and $\mathrm{MnO}_{2}$, or other species was not detected in the XRD pattern of $10 \%$ MnCo (6:1)/MCM-41, indicating that no $\mathrm{Co}_{3} \mathrm{O}_{4}, \mathrm{CoO}, \mathrm{MnO}, \mathrm{Mn}_{3} \mathrm{O}_{4}, \mathrm{Mn}_{2} \mathrm{O}_{3}$, and $\mathrm{MnO}_{2}$ crystal phases existed in the MnCo/MCM-41 composite oxide system, or that they existed in highly dispersed or amorphous forms. Thus, $\mathrm{Mn}^{4+}$ and $\mathrm{Mn}^{3+}$ were the main crystallite phase species that existed in the prepared MnCo/MCM-41 oxide catalysts.

\subsection{HRTEM and EDS analysis}

Fig. 4 shows the HRTEM images and the EDS spectra of the samples. Fig. 4(a) shows that MCM-41 had a well-ordered hexagonal array structure. Fig. 4(b) shows that the particles of $\mathrm{MnO}_{2}$ and $\mathrm{Co}_{3} \mathrm{O}_{4}$ dispersed uniformly. The EDS spectrum clearly confirmed the existence of $\mathrm{Mn}, \mathrm{Co}$, and $\mathrm{O}$, which indicated the successful loading of the active components on the surface of MCM-41.

\section{5. $\quad N_{2}$ adsorption-desorption analysis}

Fig. 5 shows the $\mathrm{N}_{2}$ adsorption-desorption isotherms of the samples. The $A_{\mathrm{BET}}, V_{\mathrm{p}}$, and average pore size of the samples are summarized in Table 1 . From the figure and table, a distinct capillary condensation phenomenon could be observed at relative pressures between 0.45 and 0.85 , indicating the
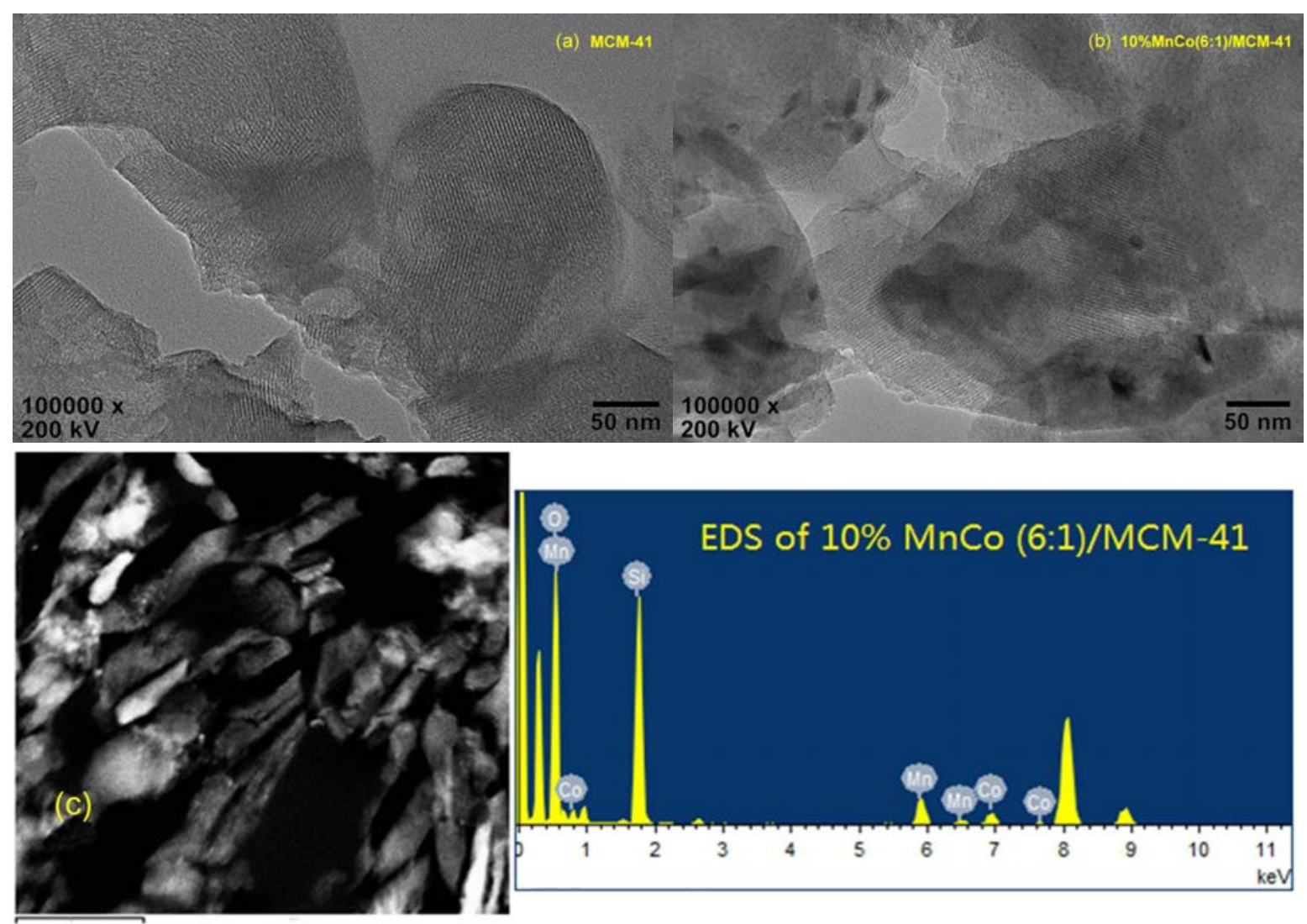

$1 \mu \mathrm{m}$

Fig. 4. HRTEM images of (a) MCM-41; (b) 10\% MnCo (6:1)/MCM-41; (c) EDS spectrum of 10\% MnCo (6:1)/MCM-41. 


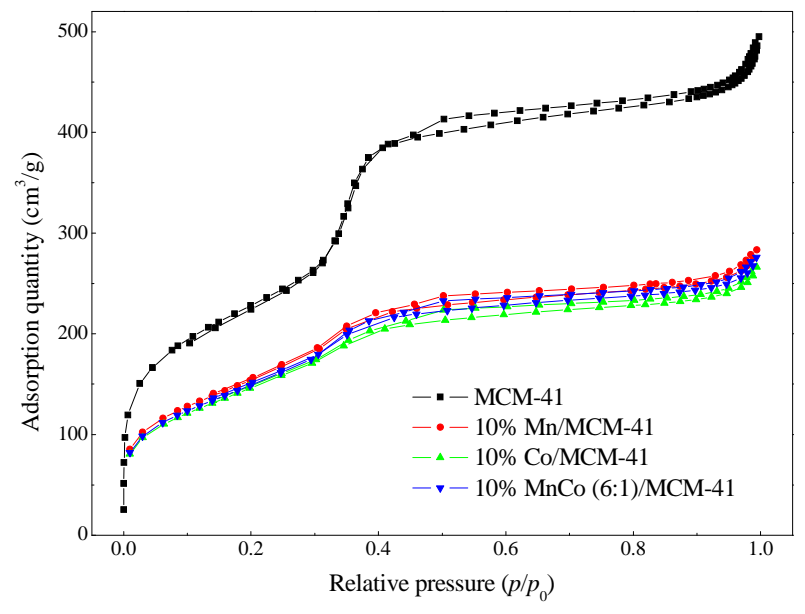

Fig. 5. $\mathrm{N}_{2}$ adsorption-desorption isotherms for MCM-41 and different supported catalysts.

presence of uniform mesopores. The existence of micropores was also confirmed by the $\mathrm{N}_{2}$ adsorption-desorption isotherms rising sharply giving $0 \sim 0.3\left(p / p_{0}\right)$. And it could be found, for those supported active components materials, all their $A_{\mathrm{BET}}, V_{\mathrm{p}}$, pore size and adsorption quantity reduced compared with MCM-41. It was probably attributed to that the oxides of Mn and Co blocked the pores of MCM-41. With the addition of Mn and Co, the relative content of MCM-41 decreased, this also makes the $A_{\mathrm{BET}}, V_{\mathrm{p}}$, pore size and adsorption quantity of the samples smaller.

\section{6. $H_{2}$-TPR analysis}

Fig. 6 shows the $\mathrm{H}_{2}$-TPR profile of the MnCo/MCM- 41 catalysts which supported different molar ratios of $\mathrm{Mn}$ and $\mathrm{Co}$. The reduction of the $10 \% \mathrm{Mn} / \mathrm{MCM}-41$ catalyst occurred at 267 , 288 , and $510{ }^{\circ} \mathrm{C}$. The $10 \% \mathrm{Co} / \mathrm{MCM}-41$ was reduced in two steps [39]: the first peak centered at $270{ }^{\circ} \mathrm{C}$ was attributed to the reduction of $\mathrm{Co}^{3+}$ to $\mathrm{Co}^{2+}$, whereas the second step reduction proceeded at $341{ }^{\circ} \mathrm{C}$ and was attributed to the subsequent reduction of $\mathrm{Co}^{2+}$ to $\mathrm{Co}$. Compared with above two catalysts, the reduction peaks of $10 \%$ MnCo (6:1)/MCM-41 catalyst were shifted to a lower temperature. This shift indicated that the oxidation property of catalyst was improved because of the interaction between $\mathrm{MnO}_{x}, \mathrm{CoO}_{x}$, and $\mathrm{MCM}-41$. The $\mathrm{Mn}-\mathrm{O}$ chemical bonds that existed in the $\mathrm{MnCoO}_{x}$ composite compounds could be weakened by the strong interaction; the weakened Mn-O chemical bonds could react with hydrogen molecules to achieve reduction at a low temperature. There-

\section{Table 1}

Specific surface area, pore volume and pore size for MCM- 41 and supported catalysts.

\begin{tabular}{lccc}
\hline Sample & $A_{\text {BET }} /\left(\mathrm{m}^{2} / \mathrm{g}\right)$ & $V_{\mathrm{p}} \mathrm{b} /\left(\mathrm{cm}^{3} / \mathrm{g}\right)$ & $d \mathrm{c} / \mathrm{nm}$ \\
\hline MCM-41 & 805.9 & 0.795 & 7.45 \\
10\% Mn/MCM-41 & 561.8 & 0.436 & 3.21 \\
10\% Co/MCM-41 & 536.7 & 0.403 & 3.23 \\
10\% MnCo (6:1)/MCM-41 & 545.4 & 0.502 & 3.43 \\
\hline
\end{tabular}

a BET specific surface area. ${ }^{\mathrm{b}}$ Total pore volume estimated at $p / p_{0}=0.99$.

c Average pore size.

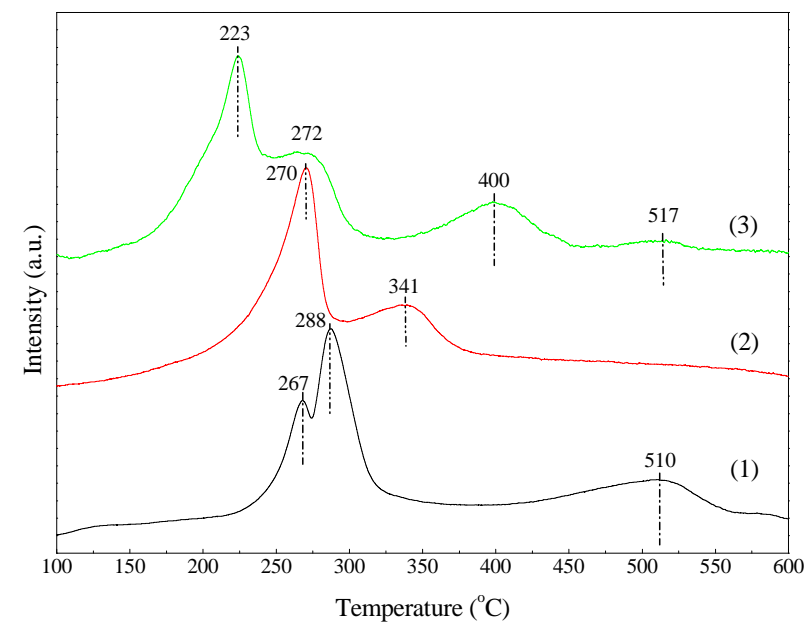

Fig. 6. Catalysts $\mathrm{H}_{2}$-TPR profile for (1) $10 \% \mathrm{Mn} / \mathrm{MCM}-41$; (2) $10 \%$ Co/MCM-41; (3) 10\% MnCo (6:1)/MCM-41.

fore, the supported MnCo composite compounds showed high oxidability at a low reduction temperature. The high low-temperature oxidability could produce reactive oxygen species at a low reaction temperature. Thus, the supported MnCo composite compound catalysts provided high catalytic combustion activity for organic compounds [40]. The catalytic activity of the mixed-oxides-based catalysts depended on the redox properties of the $\mathrm{Mn}^{4+} / \mathrm{Mn}^{3+}$ system that were present on the surface of the oxides. That was probably modulated by the quantity of the manganese employed in the synthesis, as well as the use of cobalt with the activity to promote redox cycles [41]. These were maybe the synergistic effect.

\section{7. $\quad$ CB-TPD analysis}

Fig. 7 shows the CB adsorption-desorption profiles of the support and the catalysts in the TPD test. For supported catalysts, some $\mathrm{Mn}$ or Co particles entered into the pores of the supports, which caused the adsorption capacity of CB reducing than MCM-41. However, bimetal-oxide-based catalyst had larger adsorption capacity of CB than that of single metal oxide catalysts. The order of $\mathrm{CB}$ adsorption capacity was as follows: $10 \%$ Co/MCM-41 < 10\% Mn/MCM-41 < 10\% MnCo (6:1)/MCM-41 < MCM-41. The desorption temperatures of the supported catalysts increased, which indicated the increased adsorption ability of CB. Higher desorption temperature implied higher adsorption strength for CB. The order of CB desorption temperatures was as follows: MCM-41<10\% Co/MCM-41 < 10\% Mn/MCM-41 < 10\% MnCo (6:1)/MCM-41. Surely, larger adsorption capacity and stronger adsorption ability of the catalysts are both beneficial for combustion of CB. In other words, $10 \%$ MnCo (6:1)/MCM-41 catalyst had the best combustion activity for CB. This conclusion was consistent with the result of the activity evaluation experiments.

\section{Conclusions}

In this paper, mixed oxides with active binary phases based 

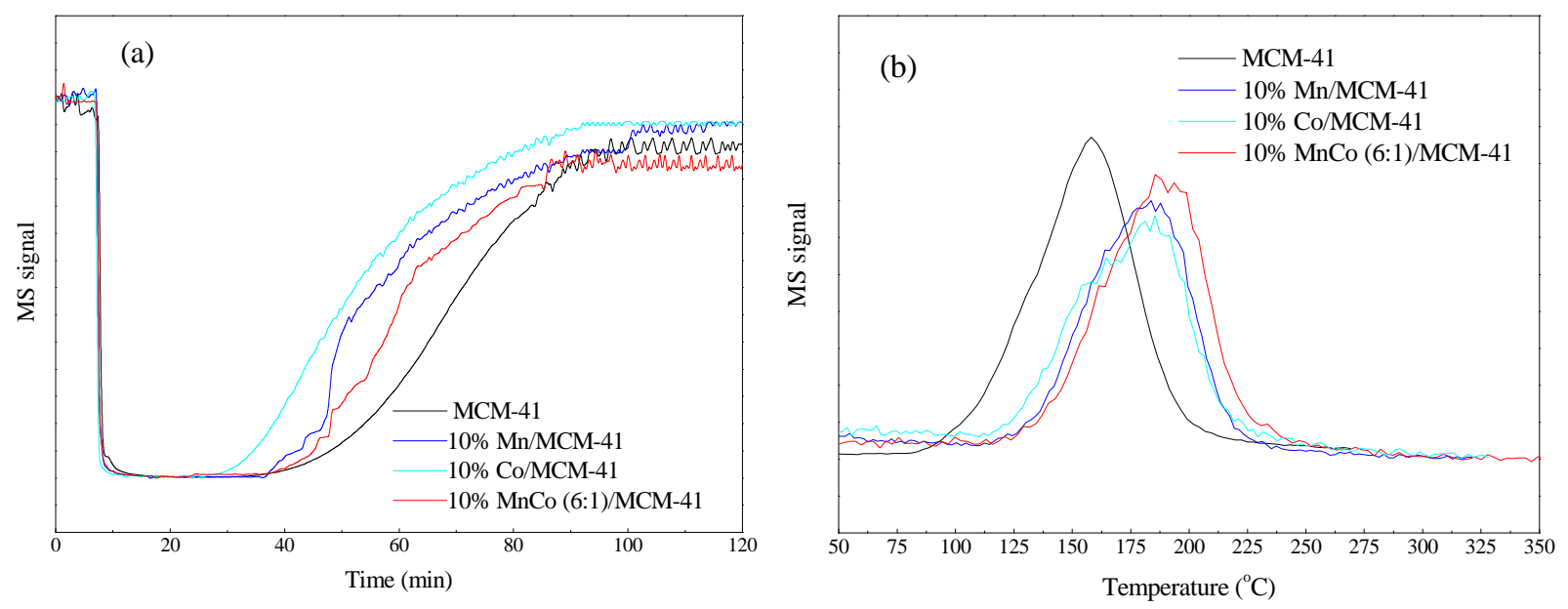

Fig. 7. The CB-TPD patterns of the catalysts. (a) CB adsorption; (b) CB desorption.

on MCM-41 catalysts were prepared. The performance of CB combustion over MnCo/MCM-41 catalysts was studied. The activity tests showed that the $10 \%$ MnCo (6:1)/MCM-41 catalyst had the highest catalytic activity. The complete conversion of CB was achieved at $270{ }^{\circ} \mathrm{C}$. The texture, structure, morphology, dispersion of the active components, and the oxidation properties of catalysts were characterized by a series of techniques. The catalytic behavior of the catalysts was significantly affected by the molar ratios of the metal oxides and the interaction between the supported components. The XRD indicated the formation of $\mathrm{MnCoO}_{x}$ compounds for $10 \%$ MnCo (6:1)/MCM-41 catalyst. The HRTEM-EDS indicated a better dispersion of Mn or Co oxides on MCM-41 for 10\% MnCo (6:1)/MCM-41 catalyst. The $\mathrm{N}_{2}$ adsorption-desorption and CB-TPD results showed that some particles of the supported components could enter into the pores, resulting in a smaller specific surface area, pore volume, pore size, and lower adsorption quantity of CB. Furthermore, the durability test demonstrated that there was no deactivation for $10 \%$ MnCo (6:1)/MCM-41 catalyst during a $1000 \mathrm{~h}$ continuous reaction. This research provides valuable information for the development of better catalysts with wide-spread applications.

\section{References}

[1] L. Zhang, Y. X. Peng, J. Zhang, L. Chen, X. J. Meng, F. S. Xiao, Chin. J. Catal., 2016, 37, 800-809.

[2] Y. X. Liu, J. G. Deng, S. H. Xie, Z. W. Wang, H. X. Dai, Chin. J. Catal., 2016, 37, 1193-1205.

[3] J. W. Kan, B. Li, L. Li, X. J. Wang, Y. W. Chen, S. M. Zhu, S. B. Shen, Chem. Ind. Eng. Progr., 2016, 35, 499-505.

[4] S. F. Zuo, M. L. Ding, J. Tong, L. C. Feng, C. Z. Qi, Appl. Clay Sci., 2015, 105-106, 118-123.

[5] V. H. Vu, J. Belkouch, A. Ould-Dris, B. Taouk, J. Hazard. Mater., 2009, 169, 758-765.

[6] M. Nikoorazm, F. Ghorbani, A. Ghorbani-Choghamarani, Z. Erfani, Chin. J. Catal., 2017, 38, 1413-1422.

[7] Y. Han, F. S. Xiao, Chin. J. Catal., 2003, 24, 149-158.

[8] M. H. Yuan, C. C. Chang, C. Y. Chang, W. C. Liao, W. K. Tu, J. Y. Tseng, D. R. Ji, J. L. Shie, Y. H. Chen, J. Taiwan Inst. Chem. Eng., 2015, 53,
52-57.

[9] S. Pitkäaho, L. Matejova, S. Ojala, J. Gaalova, R. L. Keiski, Appl. Catal. $B, 2012,113-114,150-159$.

[10] Z. E Assal, S. Ojala, S. Pitkäaho, L. Pirault-Roy, B. Darif, J. D. Comparot, M. Bensitel, R. L. Keiski, R. Brahmi, Chem. Eng. J., 2017, 313, 1010-1022.

[11] J. D. Liu, T. T. Zhang, A. P. Jia, M. F. Luo, J. Q. Lu, Appl. Surf. Sci., 2016, 369, 58-66.

[12] C. H. Zhang, C. Wang, W. C. Hua, Y. L. Guo, G. Z. Lu, S. Gil, A. Giroir-Fendler, Appl. Catal. B, 2016, 186, 173-183.

[13] W. Wang, Q. Zhu, Q. G. Dai, X. Y. Wang, Chem. Eng. J., 2017, 307, 1037-1046.

[14] S. Cao, H. Q. Wang, F. X. Yu, M. P. Shi, S. Chen, X. L. Weng, Y. Liu, Z. B. Wu, J. Colloid Interf. Sci., 2016, 463, 233-241.

[15] W. Deng, Q. G. Dai, Y. J. Lao, B. B. Shi, X. Y. Wang, Appl. Catal. B, 2016, 181, 848-861.

[16] L. Wang, H. K. Xie, X. D. Wang, G. Z. Zhang, Y. L. Guo, Y. Guo, G. Z. Lu, Chin. J. Catal., 2017, 38, 1406-1412.

[17] P. Yang, J. R. Li, S. F. Zuo, Chem. Eng. Sci., 2017, 162, 218-226.

[18] Y. Yan, L. Wang, H. P. Zhang, X. Y. Zhang, Sep. Purif. Technol., 2017, 175, 213-221.

[19] P. Yang, S. S. Yang, Z. N. Shi, Z. H. Meng, R. X. Zhou, Appl. Catal. B, 2015, 162, 227-235.

[20] P. Yang, S. F. Zuo, R. X. Zhou, Chem. Eng. J., 2017, 323, 160-170.

[21] Q. Q. Huang, Z. H. Meng, R. X. Zhou, Appl. Catal. B, 2012, 115-116, 179-189.

[22] Q. Q. Huang, X. M. Xue, R. X. Zhou, J. Mol. Catal. A, 2011, 344, 74-82.

[23] P. Yang, X. M. Xue, Z. H. Meng, R. X. Zhou, Chem. Eng. J., 2013, 234, 203-210.

[24] Q. Q. Huang, X. M. Xue, R. X. Zhou, J. Hazard. Mater., 2010, 183, 694-700.

[25] M. Wu, X. Y. Wang, Q. G. Dai, Y. X. Gu, D. Li, Catal. Today, 2010, 158, 336-342.

[26] C. H. Xu, C. Q. Liu, Y. Zhong, X. Z. Yang, J. Y. Liu, Y. C. Yang, Z. X. Ye, Chin. Chem. Lett., 2008, 19, 1387-1390.

[27] A. Z. Abdullah, M. Z. Abu Bakar, S. Bhatia, J. Hazard. Mater., 2006, $129,39-49$.

[28] D. Li, Y. Zheng, X. Y. Wang, Appl. Catal. A, 2008, 340, 33-41.

[29] X. Y. Wang, Q. G. Dai, Y. Zheng, Chin. J. Catal., 2006, 27, 468-470.

[30] J. L. Zhao, G. Qian, F. Y. Li, J. Zhu, S. F. Ji, L. Li, Chin. J. Catal., 2012, 


\title{
Graphical Abstract
}

Chin. J. Catal., 2018, 39: 849-856 doi: 10.1016/S1872-2067(17)62950-4

\section{Preparation of MnCo/MCM-41 catalysts with high performance for chlorobenzene combustion}

Zhen Cheng, Jingrong Li, Peng Yang, Shufeng Zuo *

Shaoxing University

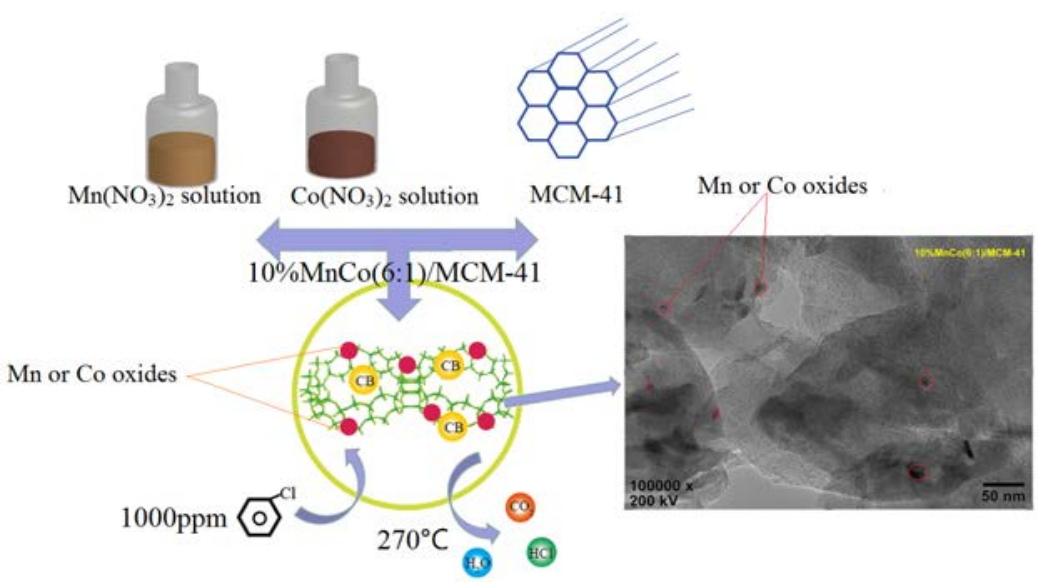

MCM-41 supported mixed oxides catalysts were synthesized by an impregnation method. The $10 \%$ MnCo (6:1)/MCM-41 catalyst showed the highest activity for chlorobenzene combustion.

33, 771-776.

[31] T. A. Konovalova, Y. L. Gao, R. Schad, L. D. Kispert, C. A. Saylor, L. C. Brunel, J. Phys. Chem. B, 2001, 105, 7459-7464.

[32] J. R. Li, S. F. Zuo, P. Yang, C. Z. Qi, Mater., 2017, 10, 949.

[33] J. W. Kan, L. Deng, B. Li, Q. Huang, S. M. Zhu, S. B. Shen, Y. W. Chen, Appl. Catal. A, 2017, 530, 21-29.

[34] M. Wu, X. Y. Wang, Q. G. Dai, D. Li, Catal. Commun., 2010, 11, 1022-1025.

[35] M. Wu, X. Y. Wang, Q. G. Dai, Y. X. Gu, D. Li, Catal. Today, 2010, 158, 336-342.

[36] S. F. Zuo, P. Yang, X. Q. Wang, ACS Omega, 2017, 2, 5179-5186.
[37] W. Zhao, J. Cheng, L. N. Wang, J. L. Chu, J. K. Qu, Y. H. Liu, S. H. Li, H. Zhang, J. C. Wang, Z. P. Hao, T. Qi, Appl. Catal. B, 2012, 127, 246-254.

[38] G. L. Zhou, X. L. He, S. Liu, H. M. Xie, M. Fu, J. Ind. Eng. Chem., 2015, 21, 932-941.

[39] T. Cai, H. Huang, W. Deng, Q. G. Dai, W. Liu, X. Y. Wang, Appl. Catal. $B$, 2015, 166-167, 393-405.

[40] G. L. Zhou, X. L. He, S. Liu, H. M. Xie, M. Fu, J. Ind. Eng. Chem., 2014, 5, 21, 932-941.

[41] D. A. Aguilera, A. Perez, R. Molina, S. Moreno, Appl. Catal. B, 2011, 104, 144-150.

\section{MnCo改性的MCM-41催化剂用于氯苯催化燃烧的研究}

\author{
成珍, 李敬荣, 杨 鹏, 左树锋*
}

绍兴文理学院, 浙江省精细化学品传统工艺替代技术研究重点实验室, 浙江绍兴312000

摘要: 含氯挥发性有机化合物(CVOCs)是对人体健康和环境危害极大的有机化合物. 常见的有二氯乙烷、三氯乙烯、三氯 甲烷、四氯化碳和氯苯等. 有些CVOCs是“三致”(致畸、致癌、致突变)物质, 有些少量进入大气就能破坏臭氧层, 亦或与臭 氧等形成光化学烟雾, 引起全球变暖. 因此, 对于其消除迫在眉睫. CVOCs通常采用高温直接燃烧、吸附、光催化氧化和催 化燃烧等方法降解. 其中, 催化燃烧是非常有效的. 我们选择氯苯作为CVOCs探针分子是因其不仅存在于农药和化工产品 中, 在室内环境中也大量存在, 而负载贵金属和非贵金属型催化剂可用于其催化降解. 贵金属催化剂价格高而且易氯中毒,

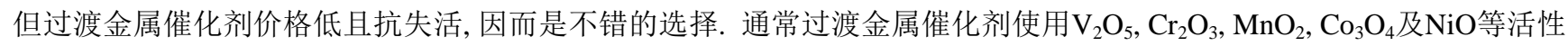
组分, 而 Mn 和Co 氧化物有较好活性且没有环境污染, 常用作活性组分. 另外, MCM-41是有序介孔硅酸盐和硅铝酸盐家族 中 M41S的一员, 具有高的比表面积和较窄的孔径分布, 常用作催化剂的载体. 我们利用具有大比表面积、大孔径的 MCM-41作为载体, 采用浸渍法负载 $\mathrm{MnO}_{x}, \mathrm{CoO}_{x}, \mathrm{MnO}_{x}-\mathrm{CoO}_{x}$ 等活性组分, 制备系列的催化剂用于低浓度氯苯的催化燃烧, 研究催化剂的催化活性、选择性及稳定性. 并利用XRD、 $\mathrm{N}_{2}$ 吸脱附、高分辨电镜-能谱分析、 $\mathrm{H}_{2}-\mathrm{TPR}$ 和CB-TPD等手段对 MCM-41及催化剂的织构-结构、表面形貌、活性组分分散状态、氧化还原性能及吸附性能等做了系统的研究.

采用表面活性剂软模板技术合成了具有大比表面积、大孔径、耐热稳定性高的MCM-41介孔分子䇛, 负载不同比例的 
$\mathrm{Mn} / \mathrm{Co}$ (摩尔比是3:1、6:1及9:1, 其中总负载量为 $10 \%$ ), 以氯苯催化燃烧为探针反应, 篎选出活性最佳时的 $\mathrm{Mn} / \mathrm{Co}$ 比例. 活性 评价实验结果表明, 各催化剂的活性以下列顺序依次降低: MnCo(6:1)/MCM-41> MnCo (9:1)/MCM-41 > MnCo (3:1)/MCM-41 > Mn/MCM-41 > Co/MCM-41, 其中MnCo(6:1)/MCM-41活性最佳, 在270 ${ }^{\circ} \mathrm{C}$ 即可完全催化燃烧氯苯. 而久性 实验结果显示, MnCo (6:1)/MCM-41在连续反应1000 h后, 其活性没有降低, 表明其具有非常良好的稳定性. XRD实验结果 表明, 在 $\mathrm{Mn} / \mathrm{MCM}-41$ 及 $\mathrm{Co} / \mathrm{MCM}-41$ 催化剂上分别检测到 $\mathrm{MnO}_{2}$ 及 $\mathrm{Co}_{3} \mathrm{O}_{4}$ 的特征衍射峰. 在 MnCo (6:1)/MCM-41催化剂上, $\mathrm{MnO}_{2}$ 及 $\mathrm{Co}_{3} \mathrm{O}_{4}$ 的特征衍射峰消失, 同时出现了 $\mathrm{MnCoO}_{x}$ 的特征衍射峰, 这是由于 $\mathrm{MnO}_{2}$ 及 $\mathrm{Co}_{3} \mathrm{O}_{4}$ 的强相互作用经过焙烧后形 成的, 且 $\mathrm{MnCoO}_{x}$ 的特征衍射峰较小, 表明双金属活性组分的分散比单金属催化剂好. $\mathrm{N}_{2}$ 吸脱附结果显示, MCM-41的比表 面积达到 $805.9 \mathrm{~m}^{2} / \mathrm{g}$, 孔体积达到 $0.795 \mathrm{~cm}^{3} / \mathrm{g}$. 负载活性组分后其比表面积及孔体积均有不同程度的减小, 这是由于活性组 分进入了MCM-41的孔隙. 高分辨电镜结果表明, MCM-41具有均匀的介孔孔道结构, $\mathrm{MnCoO}_{x}$ 在MCM-41表面的颗粒小, 分 散好. 能谱扫描出Mn, Co, O等元素, 表明活性组分成功地负载在MCM-41载体上. $\mathrm{H}_{2}-\mathrm{TPR}$ 表明, 双金属催化剂的还原峰温 较单金属催化剂低, 表明其具有更好的氧化性能. CB-TPD结果表明, MnCo双金属催化剂脱附氯苯的温度高于单金属催化 剂, 说明氯苯与催化剂之间的相互作用更强, 即双金属催化剂对氯苯的吸附能力更强, 使得氯苯催化燃烧更加充分, 因此其 催化性能更好. 同时, 深入探讨了 $\mathrm{MnO}_{x}, \mathrm{CoO}_{x}, \mathrm{MnCoO}_{x}$ 和MCM-41之间的相互作用及对催化燃烧性能的影响.

关键词: MCM-41分子篮; Mn/Co; 催化燃烧; 氯苯; 表征

收稿日期: 2017-11-18. 接受日期: 2017-12-25. 出版日期: 2018-04-05.

*通讯联系人. 电话: (0575)88345681; 传真: (0575)88345682; 电子信箱: sfzuo@usx.edu.cn

基金来源：国家自然科学基金(21577094).

本文的全文电子版由Elsevier出版社在ScienceDirect上出版(http://www.sciencedirect.com/science/journal/18722067). 